\title{
Development, Validity and Reliability of Depression Level Inventory (DLI)
}

\author{
Mohammad Aziz Shah Mohamed Arip, Suriati Zaimie, Syamsul Afandi \\ Badulzaman, Fauziah Mohd Sa'ad
}

To Link this Article: http://dx.doi.org/10.6007/IJARBSS/v11-i12/10904

DOI:10.6007/IJARBSS/v11-i12/10904

Received: 23 October 2021, Revised: 29 November 2021, Accepted: 10 December 2021

Published Online: 19 December 2021

In-Text Citation: (Arip et al., 2021)

To Cite this Article: Arip, M. A. S. M., Zaimie, S., Badulzaman, S. A., \& Sa'ad, F. M. (2021). Development, Validity and Reliability of Depression Level Inventory (DLI). International Journal of Academic Research in Business and Social Sciences, 11(12), 1181-1198

\section{Copyright: (c) 2021 The Author(s)}

Published by Human Resource Management Academic Research Society (www.hrmars.com)

This article is published under the Creative Commons Attribution (CC BY 4.0) license. Anyone may reproduce, distribute, translate and create derivative works of this article (for both commercial and non0-commercial purposes), subject to full attribution to the original publication and authors. The full terms of this license may be seen at: http://creativecommons.org/licences/by/4.0/legalcode

Vol. 11, No. 12, 2021, Pg. 1181 - 1198

Full Terms \& Conditions of access and use can be found at http://hrmars.com/index.php/pages/detail/publication-ethics 


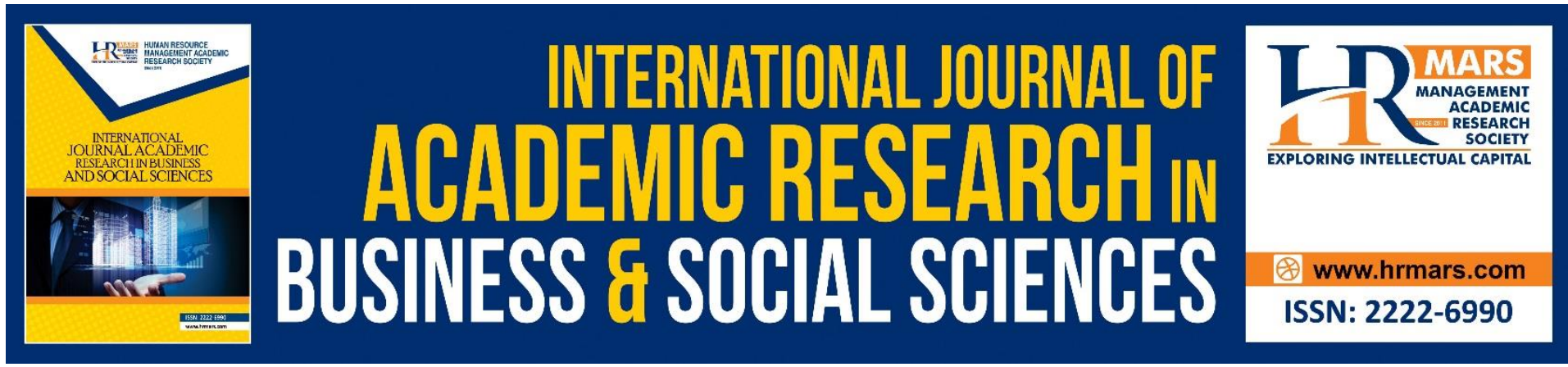

\title{
Development, Validity and Reliability of Depression Level Inventory (DLI)
}

\author{
Mohammad Aziz Shah Mohamed Arip \\ Professor, Faculty of Human Development, Sultan Idris Education University, 35900 \\ Tanjong Malim, Perak, Malaysia
}

\begin{abstract}
Suriati Zaimie, Syamsul Afandi Badulzaman
Faculty of Human Development, Sultan Idris Education University, 35900 Tanjong Malim, Perak, Malaysia
\end{abstract}

Fauziah Mohd Sa'ad

Senior Lecturer, Faculty of Human Development, Sultan Idris Education University, 35900

Tanjong Malim, Perak, Malaysia

\begin{abstract}
The purpose of this study is to build, test the content validity and reliability of Depression Level Inventory (DLI). DLI is built based on the Cognitive-Behavioral Therapy (CBT) introduced by Aaron T. Beck in 1964. DLI contains 21 negative items divided into 3 sub-scales and each sub-scale contains of 7 items. These three sub-scales are Sub-Scale 1: Depression Thinking, Sub Scale 2: Depression Emotions and Sub-Scale 3: Depression Behavior. The content validity of DLI is evaluated by 12 expert panels comprising psychologists, counseling, education and human resource management. Reliability analysis consisted of 45 respondents aged 18-21. The overall validity of DLI was high at $0.873(87.3 \%)$. The overall reliability value was .838 . As such, this study has produced an DLI questionnaire that has good validity and reliability and is useful to use in the field of psychology, guidance and counseling in Malaysia.
\end{abstract}

Keywords: Depression Level Inventory, Content Validity, Reliability, Cognitive Behavioral Therapy, Counseling, Psychology

\section{Introduction}

Depression is one of a psychiatric disorder that involves a destruction of a person's emotions. Usually, those who experienced depression will show feeling of sadness, depressed, low selfesteem, lifeless, hopeless and always blame themselves on everything that happened in their life (WHO, 2017). A sad feeling of the individuals who suffered from depression is different from those who experience a traumatic event. That sad feeling can occur either every time or every day and sometimes can be prolong until weeks (WHO, 2017). The Depression Level Inventory (DLI) was developed to assess the depression level and symptoms on a person. There are three elements that will be measure in DLI, which are the patient's thoughts, feelings and behaviors. DLI also can be used as a mental health screening tool in Malaysia. 
Depression is also the same as other mental health diseases. There are many factors that caused depression such as genetic, chemical imbalance and environmental factors. Those who have families who used to have depression, the tendency for other family members to have depression is three times higher. The factor of chemical imbalance (Neurotransmitter) were usually related with Serotonin. Besides that, Norepinephrine and Dopamine were also involved. This type of chemical is important for our brain to function normally and control our emotions. The environmental factors were known as a stressor that occurred to a person that experiences such as chronic pains, physical disabilities, did not get family supports and experience a sad incident (Hussain, 2018).

There are various efforts were made to provide awareness and guidance in dealing with depression in Malaysia. A program that's related with it was the 'Let's Talk Healthy Mind'. Although the link between suicide and mental disorders (especially depression and alcohol usage disorders) is well known and has been given awareness, many suicide cases occurred increasingly in time of crisis. Suicide is the second leading cause of death for 15-29 years old worldwide (Ministry of Health Malaysia, 2019). Campaigns and seminars on mental health awareness were also organized by the Ministry of Health Malaysia along with other agencies. Among them is the Mental Health Awareness Campaign organized by University Technology Malaysia (UTM) on 20th April 2019 with the objective of raising awareness and providing knowledge about mental health towards the public (UTM Official Portal, 2019). Next, a psychology seminar in the southern zone level of the Malaysian Prison Department that was held to enhance the cooperation culture, cohesion and tolerance in the organization and able to guide the staffs to focus on emotional and mental intelligence while performing tasks in the prison counseling department. Counseling and psychotherapy services also provided by the government and private organizations for patients who are seeking for depression treatment. A thorough evaluation by a doctor is necessary before a diagnosis was made and treatment such as pharmacotherapy, psychological therapy, cognitive therapy, group therapy and electroconvulsive therapy (Ministry of Health, 2019).

The results of the World Health Organization (WHO, 2017) report on the global health survey in 2015 found that globally the total number of individuals suffering from depression in the world is 322 million people. Almost half of that number consists of the population of the Southeast Asian region 27\% and the Western Pacific region 21\%. Based on Diagnostic and statistical manual of mental disorders 5th edition (DSM 5), the diagnosis of major depressive disorder is based on certain symptoms that is when the individual shows emotional instability such as feeling depressed, depressed, sad, sad, lack of enthusiasm, loss of interest or pleasure in almost all activities formerly preferred for at least two weeks (American Psychiatric Association, 2013). Sometimes, the symptoms of major depressive disorder are difficult to observe through individual emotional changes. However, it can be identified through the facial expressions and anxiety of the individual during the interview process between the psychiatrist and the patient.

October 10 is the day where we celebrate the World Mental Health Day annually, it was aim to raise public awareness of mental health towards the community. The theme of World Mental Health Day in 2019 is 'Working Together to Prevent Suicide' or 'Together Prevent Suicide' (Director General of Health Malaysia, 2019). However, the stigma or negative perception of society towards this disease is still seen at the same level. Mental health 
problems among young people in the country are described as worrying. The 2017 National Health and Morbidity Survey revealed that out of about 5.5 million adolescents, one in 5 young people suffers from depression. In fact, one in 10 adolescents is reported to experience emotional stress (Institute of Public Health, 2018). The National Health and Morbidity Survey conducted in 2015 by the Ministry of Health Malaysia (MOH) found that the prevalence of mental health problems among Malaysians aged 16 years and above is $29.2 \%$ (approximately 4.2 million). This means that 1 in 3 Malaysians experience issues related to mental problems. This study also shows that the prevalence of mental health is also highest among those aged 16-19 years and among the low-income group (Minister of Health Malaysia, 2016).

\section{Background of Study}

Depression Level Inventory (DLI) is an inventory to measure the level and symptoms of depression on a person as based on the Cognitive Behavioral Therapy (CBT) introduce by Aaron T. Beck on 1964. DLI can implied for individual who aged between 18 until 21 years old. There are three elements that will be measure in this inventory, which are thoughts, emotions and behaviors of the patients. Based on Sumari et al (2019), the Behavioral Cognitive Theory or Cognitive Behavioral Therapy (CBT) emphasized on the importance of belief and thoughts systems in determining the behaviors and emotions. This theory looks on thinking as the main determination towards the behavior and emotions, then decide either the person is psychologically healthy or having a mental health disorder. With that, the main focus of this theory is to replace the disturbing thoughts into a healthy thought that could help a person having a healthy and normal daily life.

Usually, depression will also disturb an individual social function until it makes a declining effect on social relationship aspects, jobs and other functions (WHO, 2017). A diagnosis on depression will be conducted by a psychiatrist through a conversation with the suspected patient. Based on gender differences, women tend to have the highest depression disorder with $5.1 \%$ instead of men with $3.6 \%$ (WHO, 2017). An early intervention on depression disorder is important especially among women. The woman weakness and deficiency in biology, psychology and social aspects had affected them as a high-risk group to get depression instead of men (Girgus \& Yang, 2015). There are a lot of past researches in Malaysia such as to understand the prevalence of depression disorder, risk factors, choices of treatment and its effect on depression disorder with different populations in Malaysia. There are still some lacking of research among the sub groups especially men ( $\mathrm{Ng}, 2014)$.

There are a plenty of studies on the relationship between depression, anxiety and stress on student's academic achievement. One of the studies is by Salleh and Kadir (2014), the result of his study mentioned that the contributors of depression, anxiety and stress among the students was the problems on their interpersonal relationship, academic tasks burden, stressful time management, environment, financial aspects, safety, relationship in the family and outdoor activities. A study by Manna et al (2016) involving high school students in Italy aged 11 to 14 years old shows self-esteem was negatively significant with depression. The result of his study was supported with a study by Hwang et al (2016) that involves 1813 adults in Korea aged 22 until 61 years old that also shows a negative relationship between depression and self-esteem. The mental health disorder prevalence among students globally in higher education were high (Pedrelli et al., 2015). With that, this problem needs to be taken seriously because it can give a bad impact especially for the students themselves. A mental 
health disorder can give a big effect on the student physically, cognitive emotionally and interpersonally to not well functioned and effected their academic achievements (Auerbach et al., 2016; Bruffaerts et al., 2018).

The Depression Level Inventory (DLI) will be used based on the basic CBT theory consisting three subscales which are thoughts, emotions and behaviors to measure the individual's level and symptoms of depression. This research needs to be held to get a high validity and reliability value, can be useful towards the psychology and counselling field in Malaysia.

\section{Literature Review}

Kwon et al (2016) in their study on suicide attempts and gender differences among Korean adolescents who are clinically depressed found an interesting finding. This study evaluated the various variables that are likely to affect suicidal behavior by comparing groups of people that have made suicide attempts with those that have never made suicide attempts. The results of the study found that all subjects in the study had a significant depression even though they had never made a suicide attempt, but there were also subjects who had serious suicidal ideas without any suicidal behavior. It also shows that groups that have never made a suicide attempt are more likely to have a higher risk of suicide than the general population.

Kuan et al (2017) in a study on MBTI personality types and depression traits, anxiety and stress among smart and talented students stated that every people have the potential to experience life stress including smart and talented students who have unique characteristics. The results of the study found that ISTJ personality is the most dominant among smart and talented students and their level of stress and depression is in the normal to severe range, while anxiety is in the normal to very severe level. The implications of the study can help smart and talented students understand their personalities and find strategies to overcome depression, anxiety and stress as well as help them in experiencing balanced social, emotional and psychological development.

Cognitive emotion regulation is a cognitive approach used consciously by an individual to deal with information that evokes emotions and it is also an important part of actionable strategies. Garnefski et al (2017) show that the more often maladaptive means such as rumination, catastrophizing and self-blame are used, the more symptoms of depression are shown. The findings of this study are supported by the study of Jacob and Anto (2016) which shows that depression is positively correlated with the dimensions of self-blame, overthinking, thinking about misfortune, blaming others, acceptance and putting it in the right perspective.

Abdul Hamid (2019) in her study on "Levels of Mental Health Among Students of Higher Education Institutions: Literacy Studies" stated that, knowing the level of mental health is important as a first step to formulate social intervention programs such as family and university support. The findings of the study indicate to policy makers that mental health is an important factor in influencing a student. Mental health education programs, family support and mentoring programs need to be implemented or added to increase the awareness of all parties on the importance of healthy mental among students in institutions of higher learning. 
A study by Kelly et al (2018), found that sleep schedule disorders, online harassment, lack of self-esteem and self-image are mediating factors that link social media use and depression. An excessive use of social media was much related to sleep problems; for example, less sleep, need longer time to sleep and more awake than sleep. In general, teenage girls are more prone to online disorders, lack of self-confidence, and experience more serious depressive symptoms than teenage boys. According to Samsudin and Hong (2016), in the study entitled "The Relationship between Mental Health Levels and Bachelor Student Performance: A Study at Universiti Utara Malaysia" found that, mental health is an important factor that influences academic performance and holistic student welfare. Students at the Institute of Higher Learning (IPT) are prone to mental health problems due to various changes in their psychological and social influences as well as academic stress. The level of mental health of university students is an important issue because it is closely related to their academic performance as well as their overall well-being. Academic performance is one of the signals to the productivity of a student and those with high productivity are important assets to the development of the country. Past studies have shown that depression if not treated properly will have an impact on a person's biological demands and will lead to behaviors such as suicide.

\section{Basic Theoretical Development of DLI}

The Depression Level Inventory was developed based on the Cognitive Behavioral Therapy (CBT) introduced by Aaron T. Beck in 1964. CBT is an action-oriented psychosocial therapy that assumes that wrong thinking causes wrong behavior and negative emotions. It is a form of psychotherapy that aims to change how people think (cognitive) and behave, with the aim of making people feel better (Ahmad \& Nasir, 2013). CBT is based on a model that our feelings and actions are influenced by our style of thinking, not external factors. Therefore, the treatment given emphasizes the (cognitive) thinking system in an effort to change behavior and emotional state. CBT focuses on replacing negative thoughts and behaviors with positive thoughts and behaviors. CBT helps to improve self-concept and improve individual behavior (Talib et al., 2016). CBT is also known as behavior modification, training individuals to replace unwanted behaviors with healthy behaviors. Cognitive therapy helps a person see the role in his life ( Sulaiman, 2016). CBT is a highly structured therapy that is evidence-based treatment that targets the client's current problems. This treatment is oriented towards a mutually agreed goal between the client and the therapist which aims to improve emotional disorders, negative thinking styles and problem behaviors that may interfere with the client's daily life function. In summary, although these three elements can be measured separately, they are basically interconnected with each other as shown in Figure 1. 


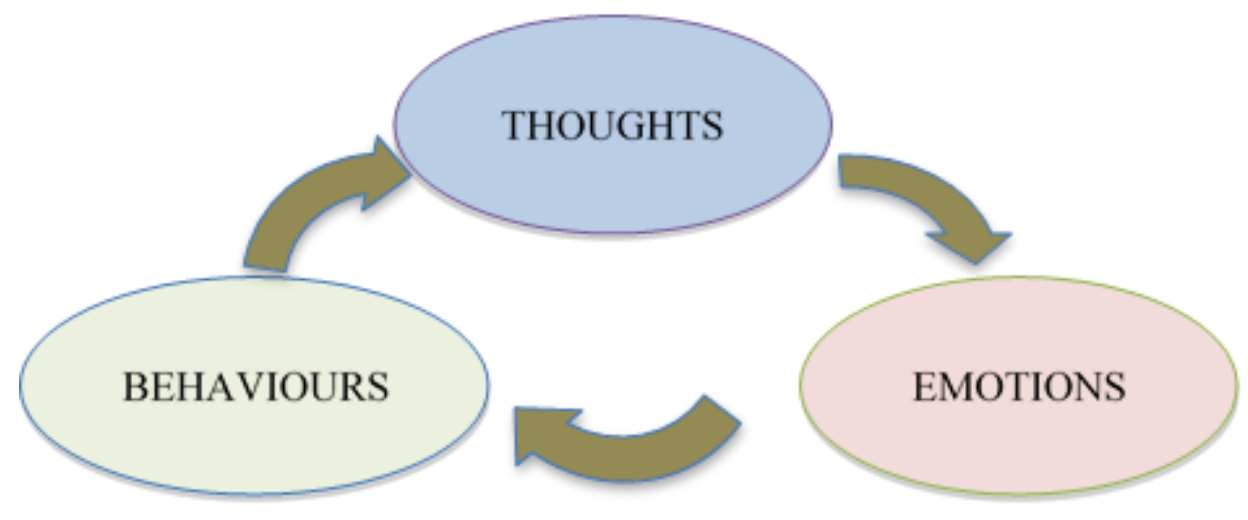

Figure 1: Subscales in Depression Level Inventory

\section{Subscale 1: Depression Thoughts}

Most signs of depression were based on an individual's negative thoughts which is not pleasant. Besides that, the changes on their thinking were also can contribute towards depression. The human's three negative thoughts were mostly about themselves, the world and also the future. A negative thought about themselves is by considering himself worthless. Then, a negative thought that was created towards the environment or world explains a depressed individual usually make an interpretation that their interactions with the environment were failed and unsuccessful. They felt that their life was always not easy and hard to overcome. Next, an individual negative thought on their future always thinks that the situation they faced now will be prolong. This situation then will affect their future to be useless and loss of hopes.

\section{Subscale 2: Depression Emotions}

An individual who have depression will always be sad. The sadness feelings can be lasting and permanent. A highly depressed person will be looked on his feelings will be too sad and gave up. They felt sadness the whole time and it is hard from the situation. They are also always worried and anxious. The sadness and giving up and other situations were seen as it will be long lasting.

\section{Subscale 3: Depression Behaviors}

The signs of depression were also based on an individual's negative behavior. A depressed person was not interested joining any activities. An inflexible perception results of beliefs or assumptions on the past experiences influence stimulus input and personality responses. Depressed individuals often misinterpret events. They will exaggerate their responsibilities and criticize themselves. They not only make an extreme generalization based on an event but will also make an illogical conclusion.

\section{Purpose of Study}

1. To develop the Depression Level Inventory (DLI) based on literature reviews.

2. To obtain the validity value of overall content and each subscale of DLI questionnaire through expert panel evaluation.

3. To obtain the reliability value of overall DLI questionnaire through Cronbach alpha coefficient analysis. 
4. To obtain the reliability value on each subscale and each item of DLI questionnaire through Cronbach alpha coefficient analysis.

\section{Administration, Scoring and Interpretation}

The Depression Level Inventory (DLI) is an inventory that measures the level and symptoms of depressions on a person. DLI consist of 21 items with 3 sub scales and each sub scales presented by 7 items. These three subscales were categorised as 1 . Depressed thoughts, 2 . Depressed Emotions and 3. Depressed Behaviors. The administration of DLI only took 10 to 15 minutes only. DLI needs to be administered in a conducive, quiet and completed with tables and chairs, stationaries such as pencil and pen and also a comfortable therapeutic place. This is because to make sure the respondents can answer the DLI questionnaire calmly without any distractions. The DLI answer form was based on a Likert scale which were Never (TP), Sometimes (J) and Always (K). Next, the researchers calculate the scores obtained from the answers filled by the respondents. For the analysis and score interpretation, DLI proposed those who scored between 29 - 42 marks shows that person have a high level of depression and also a notable depression symptom. Meanwhile, respondents who scored between $14-$ 28 shows that they scored a moderate level of depression and those who score $0-13$ indicates a low level of depression.

\section{Depression Level Inventory Scoring}

As for scorings, DLI was built with an ordinal scale such as Never, Sometimes and Always. The value of each statement was 0 for Never, 1 for Sometimes and 2 for Always. The value of each DLI items was based on the three Likert scale as mentioned in Table 1.

Table 1: Marks Scores on each DLI items

\begin{tabular}{cc}
\hline Ordinal Scale & Marks \\
\hline Never & 0 \\
Sometimes & 1 \\
Always & 2 \\
\hline
\end{tabular}

\section{Overall Analysis of Depression Level Inventory}

For the analysis and assessment on entire DLI, respondents who scored between $29-42$ shows a high level of depression. Meanwhile, the respondents who scored between $14-28$, they have a moderate level of depression and those who scored $0-13$ shows the person have a low level of depression as mentioned in Table 2.

Table 2: DLI Total Score

\begin{tabular}{cc}
\hline Total Scores & Level of Depression \\
\hline $29-42$ & High \\
$14-28$ & Moderate \\
$0-13$ & Low \\
\hline
\end{tabular}

\section{Subscales Analysis of Depression Level Inventory}

Based on the analysis and scores of assessments on each sub scales (Depressed Thoughts, Depressed Emotions and Depressed Behaviors), the respondents who scored 10-14 referred as a high level of depression, 5-9 shows a moderate level of depression and 0-4 indicates a low level of depression as mentioned in Table 3. 
Table 3: DLI Subscales Score

\begin{tabular}{cc}
\hline Subscale Scores & Level of Depression \\
\hline $10-14$ & High \\
$5-9$ & Moderate \\
$0-4$ & Low \\
\hline
\end{tabular}

Depression Level Inventory Scores Interpretation

Table 4: DLI Scores Interpretation

\begin{tabular}{|c|c|c|}
\hline $\begin{array}{l}\text { Low level of Depression } \\
\text { Score Interpretation } \\
\qquad(0-13)\end{array}$ & $\begin{array}{l}\text { Moderate Level of } \\
\text { Depression Score } \\
\text { Interpretation } \\
(14-28)\end{array}$ & $\begin{array}{l}\text { High Level of Depression } \\
\text { Score Interpretation } \\
(29-42)\end{array}$ \\
\hline $\begin{array}{l}\text { Individuals who have a low } \\
\text { level of depression always } \\
\text { be open-minded and } \\
\text { rational. They not restrain } \\
\text { themselves with negative } \\
\text { thoughts, emotions and } \\
\text { behaviors. The persons were } \\
\text { always happy and worked } \\
\text { hard to achieve their desired } \\
\text { future. They did not give up } \\
\text { and does not have any } \\
\text { problems joining themselves } \\
\text { with any community } \\
\text { activities. The person tends } \\
\text { to be thinking rationally and } \\
\text { logically before making any } \\
\text { decisions in his life. }\end{array}$ & $\begin{array}{l}\text { Individuals with moderate } \\
\text { level of depression can still } \\
\text { think calmly and rationally. } \\
\text { They are still living the } \\
\text { routine of life as usual. They } \\
\text { can still control their sad } \\
\text { feelings and still hope his life } \\
\text { changes for the better. The } \\
\text { individual is still aware of the } \\
\text { purpose and direction of } \\
\text { their life and never give up. } \\
\text { They can still socialize with } \\
\text { the community and engage } \\
\text { in outdoor activities. In } \\
\text { addition, they can still } \\
\text { control their emotions and } \\
\text { do not blame themselves } \\
\text { too often for something that } \\
\text { occurred. They can still think } \\
\text { logically in making a } \\
\text { decision. }\end{array}$ & $\begin{array}{l}\text { Individuals with high levels } \\
\text { of depression often have } \\
\text { restless thoughts. They felt } \\
\text { their life was always } \\
\text { hampered and unsuccessful } \\
\text { to overcome. They tend to } \\
\text { assume the situation they're } \\
\text { currently experiencing will } \\
\text { continue. This situation in } \\
\text { turn will make his future } \\
\text { useless and hopeless. } \\
\text { Individuals who are highly } \\
\text { depressed will show feelings } \\
\text { of too much sadness and } \\
\text { despair. They are also always } \\
\text { in a state of anxiety and not } \\
\text { interested in engaging any } \\
\text { activities with the } \\
\text { community. They were also } \\
\text { often misinterpreting } \\
\text { events. They will get } \\
\text { exaggerated with their } \\
\text { responsibilities and often } \\
\text { draw inaccuracies. }\end{array}$ \\
\hline
\end{tabular}


Table 5: DLI Subscale score Interpretation

\begin{tabular}{|l|l|l|l|}
\hline \multicolumn{1}{|c|}{ Subscale } & $\begin{array}{c}\text { Low Level } \\
\text { Depression Score } \\
\text { (0-13) }\end{array}$ & $\begin{array}{c}\text { Moderate Level } \\
\text { Depression Score } \\
(14-28)\end{array}$ & $\begin{array}{l}\text { High Level Depression } \\
\text { Score (29-42) }\end{array}$ \\
\hline $\begin{array}{l}\text { Subscale 1: } \\
\text { Depression } \\
\text { Thoughts }\end{array}$ & $\begin{array}{l}\text { Have a low risk and } \\
\text { do not think to } \\
\text { commit suicide. } \\
\text { Often think } \\
\text { rationally and live a } \\
\text { happy life. }\end{array}$ & $\begin{array}{l}\text { Have a moderate risk } \\
\text { of thinking about } \\
\text { suicide. They can still } \\
\text { think rationally and } \\
\text { living their life as } \\
\text { usual. }\end{array}$ & $\begin{array}{l}\text { Have a high risk of } \\
\text { often thinking on } \\
\text { committing suicide. } \\
\text { Often plagued with } \\
\text { negative thoughts and } \\
\text { their life has no } \\
\text { future. }\end{array}$ \\
\hline $\begin{array}{l}\text { Subscale 2: } \\
\text { Depression } \\
\text { Emotions }\end{array}$ & $\begin{array}{l}\text { Able to fully control } \\
\text { their feelings of } \\
\text { sadness and not } \\
\text { anxious without any } \\
\text { reason. }\end{array}$ & $\begin{array}{l}\text { Moderate in } \\
\text { controlling the } \\
\text { sadness and felt } \\
\text { anxious without any } \\
\text { reasons. }\end{array}$ & $\begin{array}{l}\text { Have a difficulty to } \\
\text { control their feelings } \\
\text { of being too sad and } \\
\text { always feeling anxious } \\
\text { for no reason. }\end{array}$ \\
\hline $\begin{array}{l}\text { Subscale 3: } \\
\text { Depression } \\
\text { Behaviors }\end{array}$ & $\begin{array}{l}\text { Have a low risk and } \\
\text { do not tend to self- } \\
\text { harm, does not have } \\
\text { trouble with } \\
\text { sleeping and likes to } \\
\text { socialize with the } \\
\text { community. }\end{array}$ & $\begin{array}{l}\text { Have a moderate risk } \\
\text { of self-harm, no } \\
\text { problem with the } \\
\text { sleeping routine and } \\
\text { still can be socialize } \\
\text { with the community }\end{array}$ & $\begin{array}{l}\text { Have a high risk of } \\
\text { self-harm, difficult to } \\
\text { sleep and frequently } \\
\text { solitude. }\end{array}$ \\
\hline
\end{tabular}

\section{Research Method}

The design of this research is a descriptive study with a purpose to obtain the validity and reliability value of DLI. This study consists of three phases:

\section{Phase 1: Development of DLI}

The development of DLI was based on the Cognitive Behavioral Therapy (CBT) introduced by Aaron T. Beck. This inventory was built to measure the level and symptoms of depression towards a person. The 21 items that was build, will be given to the professionals for the next phase which is to get the content validity of DLI.

\section{Phase 2: Obtain the Content Validity}

In this phase, after the items were developed, DLI was given to 12 professional panels to be reviewed in the items content. The panels consist of a psychologist, counsellors, educators and human resource management. The review made by the professional panels was in order to get the content validity value of DLI. This content validity value is important as a valid explanation to present the exact characteristics and theories (Hammersley \& Atkinson, 1995). DLI have a high content validity and it was acceptable by the professionals. The questionnaire consists of a high degree of validity if it measures the things that was supposed to be measured (Konting, 1998). Next, the researcher had prepared a complete copy of DLI including the introduction of the research and its appendix to get the feedbacks and 
suggestions for improvements. The scoring scale for the evaluation is 10, 1 (Strongly Disagree), 5 (Moderately Agree) and 10 (Strongly Agree).

\section{Phase 3: Reliability Analysis}

Phase three was carried out to get the DLI reliability value. A reliability usually referred to describe an inner stable and strong questionnaire (Creswell, 2005). The basic for a great reliability value as mentioned by Kerlinger (1979) that a questionnaire that have an alpha value, $\alpha$ more than 0.6 on the significant level of 0.05 is a great value. Next, the DLI then will be administered to 45 people aged $18-21$ years old. The sampling technique used is a random sampling technique. The result of the study will be analysed by Statistical Package for the Social Sciences (SPSS) to get the Cronbach alpha value of DLI.

\section{Research Subjects}

The subjects of study only involved in phase 2 and 3 . In phase 2, the subjects of the study were 12 professional panels consist of an expert psychologist, counsellors, educators and a human resource management. Meanwhile in phase three, there are 45 respondents aged between $18-21$ years old to get the DLI reliability value.

\section{Research Findings}

\section{Result Phase 1: Development of DLI Scale, Subscale and Items}

The development of DLI was based on a literature review and information based on reference materials such as books, articles, local and international journals. Next, the basic theory on developing the main scale and subscales of DLI was by using the Cognitive Behavioral Therapy (CBT). The DLI consist of 21 items that was divided into 3 subscales which are Subscale 1: Depression Thoughts, Subscale 2: Depression Emotion and Subscale 3: Depression Behaviors. Every subscale consist of 7 items and all of the items is a negative item.

\section{Result Phase 2: DLI Value of Content Validity}

The result of the study purposes an improvement provide by the professional panels evaluation. Overall, 12 professional panels gave an approval on the items provided. The panel's point of view was referred to be the main reference for the researchers improving the items to measure the validity. The suggestions and views of the professional panels were mentioned as Table 6 below: 
Table 6: DLI Content Validity Review and Suggestion

\begin{tabular}{|c|c|c|}
\hline Panels & Improvement Suggestions & Actions \\
\hline Panel 1 & $\begin{array}{l}\text { As for Subscale 2, would be suggested to include } \\
\text { the statement about communities to measure the } \\
\text { emotions. Example of statement: } \\
\text { i. I always felt that my friends / the } \\
\text { community / my boss / my family dislike } \\
\text { me. } \\
\text { ii. I always felt I am a burden to my family. }\end{array}$ & $\begin{array}{l}\text { Actions for improvement } \\
\text { have implemented. }\end{array}$ \\
\hline Panel 2 & Every question presented was fair and can be use. & \\
\hline Panel 3 & $\begin{array}{l}\text { The statements complied with elements of the } \\
\text { research. }\end{array}$ & \\
\hline Panel 4 & $\begin{array}{l}\text { Please include the question / statement generally } \\
\text { and don't make the question asked as an answer / } \\
\text { actions in the respondent's life. }\end{array}$ & $\begin{array}{l}\text { Actions for improvement } \\
\text { have implemented. }\end{array}$ \\
\hline Panel 5 & $\begin{array}{l}\text { For Subscale } 1 \text {, suggested to include the } \\
\text { statement: I think no one wanted to be with me. }\end{array}$ & $\begin{array}{l}\text { Actions for improvement } \\
\text { have implemented. }\end{array}$ \\
\hline Panel 6 & $\begin{array}{l}\text { In subscale } 1 \text {, the question } 2 \text { and } 4 \text { gave the same } \\
\text { meaning. }\end{array}$ & $\begin{array}{l}\text { Actions for improvement } \\
\text { have implemented. }\end{array}$ \\
\hline Panel 7 & Items developed was perfect with the study. & \\
\hline Panel 8 & $\begin{aligned} & \text { i. } \text { Congratulations } \\
& \text { ii. } \text { Goodluck } \\
& \text { iii. } \text { I support this inventory } \\
&\end{aligned}$ & \\
\hline Panel 9 & Every statement was clear to be answered. & \\
\hline Panel 10 & $\begin{array}{l}\text { Congratulations and well-done. Every statement } \\
\text { clearly shows the level of depression. }\end{array}$ & \\
\hline Panel 11 & $\begin{array}{l}\text { The items were really suitable study for an } \\
\text { individual with depression. Congratulations! }\end{array}$ & \\
\hline Panel 12 & $\begin{array}{l}\text { For Subscale 1, item suggestion: } \\
\text { i. I think I don't have a future } \\
\text { For Subscale 2, item suggestion: } \\
\text { ii. I always happy without any reasons } \\
\text { For Subscale 3, item suggestion: } \\
\text { iii. I always been watched }\end{array}$ & $\begin{array}{l}\text { Actions for improvement } \\
\text { have implemented. }\end{array}$ \\
\hline
\end{tabular}

Based on the suggestions above, the researchers revised the items and make an action to improve the items. Overall, the professionals agreed that DLI can measure the depression level and potential on a person. Based on Konting (1998), the validity of the measurement tool is referred to the extent to which the instrument used measures the data required in order to achieve the objectives of the study. 
Table 7: Overall Content Validity Value and DLI Subscale $(n=12)$

\begin{tabular}{lccc}
\hline Scale / Subscale & Items & Percentage (\%) & Professional Response \\
\hline Overall DLI & 21 & $0.873(87.3 \%)$ & Acceptable \\
Depression Thoughts & 7 & $0.864(86.4 \%)$ & Acceptable \\
Depression Emotions & 7 & $0.867(86.7 \%)$ & Acceptable \\
Depression Behavior & 7 & $0.886(88.6 \%)$ & Acceptable \\
\hline
\end{tabular}

Table 7 shows the overall validity value of $\mathrm{DLI}$ is 0.873 (87.6\%). Meanwhile, the validity value for each subscale; Depression Thoughts 0.864 (86.4\%), Depression Emotions 0.867 (86.7\%) and Depression Behaviors 0.886 (88.6\%). These shows that DLI have a high validity value.

\section{Result Phase 3: DLI Reliability Value}

Phase three was performed to obtain the DLI reliability value. The data obtained have processed by using the Statistical Package for the Social Sciences (SPSS). Based on Creswell (2005), reliability shows the inner stability and strength of the questionnaire. Meanwhile, Kerlinger (1979) states a reliability coefficient between $0.60-0.80$ is moderately high and the value of 0.80 and above is high. The DLI Cronbach Alpha value was presented in the Table 8 below:

Table 8: DLI Overall and Subscale Reliability Analysis ( $n=45)$

\begin{tabular}{cccc}
\hline Analysis & Items & Cronbach Alpha & Results \\
\hline Overall DLI & 21 & .838 & High \\
Depression Thoughts & 7 & .664 & Moderately High \\
Depression Emotions & 7 & .657 & Moderately High \\
Depression Behaviors & 7 & .732 & Moderately High \\
\hline
\end{tabular}

Significant Level of 0.05

The DLI reliability analysis shows the Cronbach Alpha coefficient value is high and satisfied, the value is 0.838 . The basic reliability value of a questionnaire as mentioned by Kerlinger (1979), a questionnaire that have an alpha value more than 0.6 with a significant level of 0.05 , it is a great value. This shows that DLI have a great reliability and can measure the symptoms and level of depression. As for the DLI subscales, the reliability value is moderately high which is; Depression Thoughts 0.664, Depression Emotions 0.657 and Depression Behaviors 0.732. The DLI reliability value is high. This shows that the items were great as the value of overall DLI is 0.838 . Sekaran (1992) mentions the lowest reliability value is below than 0.6 and can't be accepted, meanwhile the value between 0.6 until 0.8 will be a moderate value and it was acceptable, if the value is more than 0.8 , then it is a high value and can be accepted too.

Next, Table 9 is a reliability analysis to assess the developed item's quality level. For DLI, the item 1-7 is for the Subscale 1: Depression Thoughts, 8-14 is for the Subscale 2: Depression Emotions and item $15-21$ is for the Subscale 3: Depression Behaviors. The result of the analysis was presented as below: 
Table 9: DLI Reliability Value on Each Items $(n=45)$

\begin{tabular}{|c|c|c|c|}
\hline & Items & $\begin{array}{l}\text { Cronbach } \\
\text { Alpha }\end{array}$ & Interpretation \\
\hline 1 & I think I am useless & .856 & High \\
\hline 2 & I think dying is better & .861 & High \\
\hline 3 & $\begin{array}{l}\text { I always have negative } \\
\text { thoughts }\end{array}$ & .838 & High \\
\hline 4 & I think I do not deserve to live & .842 & High \\
\hline 5 & $\begin{array}{l}\text { I think my opinion was } \\
\text { ignored by people }\end{array}$ & .821 & High \\
\hline 6 & I think I don't have a future & .831 & High \\
\hline 7 & $\begin{array}{l}\text { I think the community always } \\
\text { looked down on me }\end{array}$ & .820 & High \\
\hline 8 & I never felt happy with my life & .824 & High \\
\hline 9 & I often felt really worried & .826 & High \\
\hline 10 & $\begin{array}{l}\text { I find it hard to control my } \\
\text { feelings of being too sad }\end{array}$ & .841 & High \\
\hline 11 & I always blame myself & .822 & High \\
\hline 12 & $\begin{array}{l}\text { I always afraid to face the } \\
\text { society }\end{array}$ & .828 & High \\
\hline 13 & I am tired of my life & .835 & High \\
\hline 14 & $\begin{array}{l}\text { I always be anxious without } \\
\text { any reasons }\end{array}$ & .824 & High \\
\hline 15 & I always hurt myself & .828 & High \\
\hline 16 & $\begin{array}{l}\text { I always avoid to meet other } \\
\text { people }\end{array}$ & .837 & High \\
\hline 17 & $\begin{array}{l}\text { I always cried in a long period } \\
\text { of time }\end{array}$ & .828 & High \\
\hline 18 & I often anxious for no reason & .824 & High \\
\hline 19 & I have a hard time sleeping & .823 & High \\
\hline 20 & I am often alone & .823 & High \\
\hline 21 & I always feel painful & .820 & High \\
\hline
\end{tabular}

Significant level of 0.05

*All items are negative.

Based on Table 9 above, it shows the items have a high value of reliability. This shows that the quality of the developed items was in a great level, satisfied and understandable by the respondents. The result of the study was in line with a statement by Konting (1998), the reliability coefficient value of 0.60 and above is accepted.

\section{Discussion and Suggestion}

This study can give a big implication to the field of psychology and counselling in Malaysia. A basic theory will be the main framework to develop the scales and subscales of DLI, the theory used called Cognitive Behavioral Therapy (CBT). It was introduced by Aaron T. Beck. With that, DLI was built with three subscale, 21 items to measure the subscale depression thoughts, depression emotions and depression behaviors. Based on the result, DLI developed proved to 
have high reliability and validity with overall validity of 0.873 and overall reliability of .838 . It is suitable and valid to use as a screening tool to measure depression level in individuals. A great reliability value as mentioned by Kerlinger (1979), is a questionnaire that have the alpha value more than 0.6 with a significance level of 0.05 . A high content validity shows the professional panels agreed the items can measure the level and symptoms of depression. Sekaran (1992) states if the reliability value is less than 0.6, it is considered as low and unacceptable, meanwhile, the value between 0.6 until 0.8 , it is moderate and acceptable, and for the value 0.8 and above, the value is high and acceptable.

Researchers suggested a further study with DLI for the government workers especially the uniformed bodies such as Police, Firefighters, Customs and Immigrations to measure the level and symptoms of depression among them. There are a lot of challenges that may cause stress among the law enforcement officers. The Royal Malaysian Police (PDRM) is now facing a psychological problem whereby there are cases of murder, injuring the public, suicide and mental disorders (Baker \& Ibrahim, 2015). Depression, anxiety is major global risk factors contribute to worker's health, triggering workers to be less motivated and less productive. A career as a firefighter does not deprive them from having depression, anxiety and stress ( $\mathrm{Ab}$ Rahman et al., 2017). The other factors were workloads, community and order from the superiors.

DLI needs to be administered as a mental health screening to understand the symptoms of depression among Malaysian with any ages. A research by Ariffin et al (2018) explains that there needs to be an index to measure psychological well-being so that mental health issues can be controlled in the community. McGregor et al (2015) mentioned that the study on people need to have measurements specially to evaluate their well-being in a community. In the process to achieve their well-being, this kind of measurements is ideal to study the hard aspects and required an objective research. Next, it is proposed to make improvements to the scales, subscales and items to make it standardized, better quality and can be widely used involving various parties in direct or indirect counselling service. The same goes for obtaining the validity and reliability analysis.

An online based application does not need the user to download it in their computer, it only needs an internet connection to be function. A useful application name Google Apps consist of Google Spreadsheet, Google Drive, Google Form and Google Power Point (Doman, 2017). With that, researchers suggested that the DLI inventory can be download through Google Forms to ease and save time on data collections. Many respondents can also be obtained in addition to saving paper to print and make copies of questionnaires to be distributed to the respondents. This method also makes it easier for the respondents to answer easily by only using their mobile phones instead of papers.

\section{Conclusion}

In a nutshell, this study has successfully developed the Depression Level Inventory (DLI) based on the Theory of Cognitive Behavioral Therapy (CBT) which was introduced by Aaron T. Beck in 1964. The result of the study had proven each of the DLI items has a high content validity and reliability. Therefore, DLI is able to measure the level and symptoms of depression faced by the individuals. The analysis of each items also shows that the quality of the items constructed is at an excellent level, satisfied and can be understood by the respondents. 


\section{References}

Ab Rahman, O., Sufian, A., \& Kamaruzaman, Z. (2017). Depression, Anxiety and Stress Among Firefighters at One of Balai Bomba In Negeri Sembilan-A Case Study. Universiti Sains Islam Malaysia, 194-219.

Abdul Hamid, S. (2019). Tahap Kesihatan Mental Dalam Kalangan Pelajar Institut Pengajian Tinggi: Kajian Literasi. e-prosiding Persidangan Antarabangsa Sains Sosial dan Kemanusian 2019. Kolej Universiti Islam Antarabangsa Selangor.

Ariffin, A. R., Hassan, A. J., Hassan, A., Ismail, Z., \& Patola, A. (2018). Keperluan Indeks Kesejahteraan Psikologi Dalam Perkhidmatan Awam: Satu Tinjauan Umum. Jurnal Psikologi \& Kaunseling Perkhidmatan Awam Malaysia, 13.

Ahmad, N. S., \& Nasir, R. (2013). Aplikasi Praktik Teori Kaunseling dan Psikoterapi. Universiti Kebangsaan Malaysia.

American Psychiatric Association. (2013). Diagnostic and statistical manual of mentaldisorders (5th ed.). Washington, DC.

Auerbach, R. P., Alonso, J., Axinn, W., Cuijpers, P., Ebert, D., Green, J., Mortier, P. (2016). Mental disorders among college students in the World Health Organization World Mental Health Surveys. Psychological Medicine, 46(14): 2955- 2970.

Baker R., \& Ibrahim H. I. (2015). Tekanan kerja dalam organisasi kepolisan: Tinjauan dalam perspektif kecerdasan emosi. Jurnal Kemanusiaan, 23,1-24.

Bruffaerts, R., Mortier, P., Kiekens, G., Auerbach, R. P., Cuijpers, P., Demyttenaere, K., Kessler, R. C. (2018). Mental health problems in college freshmen: Prevalence and academic functioning. Journal of Affective Disorders, 225(1): 97-103.

Creswell, J. W. (2005). Educational Research: Planning, Conducting, and Evaluating Quantitative and Qualitative Research, 2nd ed., New Jersey: Pearson Education, Inc.

Director General of Health Malaysia. (2019). World Suicide Prevention Day [Press Release]. Retrieved on 30 December 2019 from

https://www.thestar.com.my/news/nation/2021/09/10/prevent-suicide-togethercreating-hope-through-action.

Doman, N. (2017). Implikasi Google Apps dalam Pengajaran dan Pembelajaran Pelajar Pesisir Uthm. Fakulti Pendidikan Teknikal dan Vokasional Universiti Tun Hussein Onn Malaysia.

Garnefski, N., Hossain, S., \& Kraaij, V. (2017). Relationships between maladaptive cognitive emotion regulation strategies and psychopathology in adolescents from Bangladesh. Arch Depress Anxiety, 3(2), 023-029.

Hammersley, M., \& Atkinson, P. (1995). Ethnography: Principles in Practice, (Second Edition), pp 263-287, London, Routledge.

Hwang, S., Kim, G., Yang, J. W., \& Yang, E. (2016). The Moderating Effects of Age on the Relationships of Self-Compassion, Self-Esteem, and Mental Health. Japanese Psychological Research, 58(2), 194-205.

Institute of Public Health. (2018). National Health and Morbidity Survey (NHMS) 2017: Key finding from the adolescent health and nutrition surveys.

Jacob, M. S., \& Anto, M. M. (2016). A Study on Cognitive Emotion Regulation and Anxiety and Depression in Adults. The International Journal of Indian Psychology, 3(2), 117- 124.

Kelly, Y., Zilanawala, A., Booker, C., \& Sacker, A. (2018). Social media use and adolescent mental health: Findings from the UK Millennium Cohort Study. EClinicalMedicine, 6, 59-68. 
Kerlinger, F. N. (1979). Behavioral research: A conceptual approach. New York: Holt, Rinehart, and Winston.

Konting, M. M. (1998). Kaedah penyelidikan pendidikan. (4th ed.). Kuala Lumpur: Dewan Bahasa dan Pustaka.

Kuan, Y. S., Fuad, D. N., Karim, M., Hamdan, J., Mohd Ishak, N., \& Mahmud, M. I. (2017). Jenis Personaliti MBTI dan Trait Kemurungan, Kebimbangan dan Tekanan Dalam Kalangan Pelajar Pintar dan Berbakat. Fakulti Pendidikan Universiti Kebangsaan Malaysia, 8595.

Kwon, A., Song, J., Yook, K. H., Jon, D. I., Jung, M. H., Hong, N., \& Hong, H. J. (2016). Predictors of suicide attempts in clinically depressed Korean adolescents. Clinical Psychopharmacology and Neuroscience, 14(4), 383-387.

Manna, G., Falgares, G., Ingoglia, S., Como, M. R., \& De Santis, S. (2016). The relationship between self-esteem, depression and anxiety: Comparing vulnerability and scar model in the Italian context. Mediterranean Journal of Clinical Psychology, 4(3).

McGregor, A., Coulthard, S., \& Camfield, L. (2015). Measuring What Matters. Development Progress Project Note. 1-19.

Ministry of Health Malaysia. (2016, September 28). Mental Health Problems in Malaysia [Press Release]. Retrieved on 30 December 2019 from https://www.moh.gov.my/moh/modules_resources/english/database_stores/96/33 7_451.pdf.

Ministry of Health Malaysia. (2019, October 10). Hari Kesihatan Mental Sedunia 2019 Sayangi Nyawa, Hidupkan Harapan. Let's Talk Minda Sihat. Retrivied on 30 Decemeber 2019 from https://kpkesihatan.com/2019/10/10/kenyataan-akhbar-kpk10-oktober-2019-hari-kesihatan-mental-sedunia-2019-sayangi-nyawa-hidupkanharapan/.

$\mathrm{Ng}, \mathrm{C}$. G. (2014). A review of depression research in Malaysia. The Medical Journal of Malaysia, 69, 42-45.

Hussain, N. H. (2018). Kesihatan wanita pada usia emas: kenyataan dan harapan. Penerbit Universiti Sains Malaysia.

Pedrelli, P., Nyer, M., Yeung, A., Zulauf, C., \& Wilens, T. (2015). College students: mental health problems and treatment considerations. Academic Psychiatry, 39(5), 503-511.

Salleh, A. H., \& Kadir, D. R. (2014). Kajian mengenai hubungan antara kemurungan, kebimbangan dan tekanan dengan tret personaliti di kalangan pelajar tahun akhir Fakulti Pendidikan, Universiti Kebangsaan Malaysia.

Samsudin, S., \& Hong, K. T. C. (2016). Hubungan Antara Tahap Kesihatan Mental dan Prestasi Pelajar Sarjana Muda: Satu Kajian di Universiti Utara Malaysia. Jurnal Sains Kesihatan Malaysia (Malaysian Journal of Health Sciences), 14(1), 11-16.

Sekaran, U. (1992). Research methods for bussiness: A skill building approach. New York: John Wiley \& Sons, Inc.

Sumari, M., Tharbe, A. I. H., Khalid, M. N., \& Nor, M. A. (2015). Teori Kaunseling dan Psikoterapi. Kuala Lumpur: Universiti Malaya.

Talib, J., Mamat, M., Ibrahim, M., \& Mohammad, Z. (2016). Pembaikan Tingkah Laku Kanakkanak Sekolah rendah Melalui Terapi Kognitif-Tingkah Laku. UNITAR International University. Universiti Kebangsaan Malaysia.

UTM Official Portal. (2019). Kempen Kesedaran Kesihatan Mental. Retrieved on 30 Disember 2019 at https://News.Utm.My/Ms/2019/05/Kelab-Psychic-Fssk-Anjur-KempenKesedaran-Kesihatan-Mental/ 
Sulaiman, W. A. (2016). Keberkesanan Modul Intervensi Kognitif dan Terapi Tingkah Laku dalam Kaunseling Kelompok Menangani Tekanan Jururawat. Universiti Kebangsaan Malaysia.

World Health Organization. (2017). Depression and other common mental disorders: Global health estimates. Assessed on 20 December 2019. Retrieved at https://apps.who.int/iris/bitstream/handle/10665/254610/WHO-MSD-MER-2017.2eng.pdf. 